\title{
Bioelectrochemical Treatment of Contaminated Groundwater
}

\section{Marta Coma ${ }^{1}$ and Sebastià Puig ${ }^{2 *}$}

${ }^{1}$ Laboratory of Microbial Ecology and Technology (LabMET), Ghent University, Ghent, Belgium

${ }^{2}$ Laboratory of Chemical and Environmental Engineering (LEQUiA), Institute of the Environment, University of Girona, Girona, Spain

Water contamination is a worldwide environmental challenge. Consumption of water containing high nitrate, sulphate or Chlorinated Aliphatic Hydrocarbons (CAHs) levels as drinking water can cause many diseases (i.e. cancer, skin irritation, an increased risk of respiratory tract infections and goiter development in children). Both the Water Framework Directive (2000/60/EC) and the Groundwater Directive (2006/118/EC) consider these pollutants the main threats to water quality, requiring urgent and intensive monitoring and strong policies.

To remove these pollutants from groundwater, different technologies can be used. Currently, the Environmental Protection Agency (EPA) considers ion exchange, reverse osmosis and reverse electrodialysis to be effective methods for the decrease of their concentrations, below their limit in drinking water. These technologies have some drawbacks, such as low selectivity towards the target pollutant, high energy or chemicals requirements, and the generation of waste brine (pollutants are separated from water, not treated), which require an additional treatment.

Bio Electro Chemical Systems (BES) could fill this niche. BES use microorganisms to catalyse different electrochemical reactions, as well as generating electrical power from wastes [1-3], the generation of many different chemical products or biofuels $[4,5]$, and the removal of organic, and/or inorganic compounds from water flows. Groundwater, as the main resource of drinking water, is usually characterized by low conductivity (less than $1 \mathrm{mS} \cdot \mathrm{cm}^{-1}$ ). Low ionic strength influences oxidation and reduction processes (in terms of removal efficiencies and loads), and the energy and current productions [6]. Cathode over potential represents almost $80 \%$ of the total energy losses, as cathode microbial community consumes energy to catalyse reduction reactions.

Intensive agriculture and livestock production and other non point sources have led to nitrate pollution in aquifers around the world [7]. Groundwater contaminated with nitrate contains almost no organic matter. As a result, using biological denitrification in activated heterotrophic sludge systems requires the addition of an external carbon source, producing considerable amount of sludge, which should be treated before disposal. Autotrophic denitrification is a more sustainable solution because carbon is not necessary, and thus, no carbon dioxide is released, leading to better bio stability. The cathode of BES can perform autotrophic nitrogen oxidised compounds (nitrate, nitrite and even nitrous oxide) removals [8-10]. BES are capable to treat nitrates at a maximum removal of $226 \mathrm{gNO}_{3}^{-} \cdot \mathrm{m}^{-3} \cdot \mathrm{d}-1$, without no nitrous oxide emission (a greenhouse gas), neither affecting other parameters of quality [11]. Not only BES removes nitrogen oxidised compounds, they also produce electrical power $\left(0.013 \mathrm{kWh} \cdot \mathrm{m}^{-3}\right)$, if an organic waste is fed in the anode compartment.

Sulphate, one of the most abundant anions in the environment, is generated and discharged from many industrial processes. Despite its relatively low direct environmental risk compared to other pollutants, in situ sulphate reduction to sulphide (toxic, corrosive and odorous compound) may occur under anaerobic conditions. Therefore, drinking water directives fixed a control concentration of $250 \mathrm{mg}$ $\mathrm{SO}_{4}^{2-} \cdot \mathrm{L}^{-1}$. Removal of sulphate from liquid is restricted to anaerobic bioreactors coupled to oxidation of organic matter. However, sulphaterich water, as in the case of nitrate contaminated groundwater, is usually deficient in electron donors [12]. BES can provide the electrons required for sulphate reduction in a biologically activated cathode, by coupling the oxidation of organic substrates in a separated anode, or by direct power supply. Despite a minimum power supply is required to overcome activation energy, thermodynamic potential losses and cathode over potentials, sulphate can be reduced via direct electron transfer, when poising the electrode too high $(-0.26 \mathrm{~V} v s$. SHE) for appreciable hydrogen production $[13,14]$. Sulphate groundwater-like streams can be treated with a minimum energy requirement of $0.7 \mathrm{~V}$, while maximum removal of $60 \mathrm{~g} \mathrm{SO}_{4}^{2-} \cdot \mathrm{m}^{-3} \cdot \mathrm{d}^{-1}$ occurs at $1.4 \mathrm{~V}$ applied. The reduction of sulphate leads mainly to sulphide production, which is entrapped in the ionic form, thanks to high bio cathode $\mathrm{pH}$ obtained during the process [13].

Chlorinated Aliphatic Hydrocarbons (CAHs), a family of compounds that are commonly used as chlorinated organic solvents for degreasing in the dry cleaning, electronics, industrial manufacturing and machine maintenance industries, are increasingly being detected in groundwater. The most prevalent of these CAHs are perchlorethylene (PCE), trichloroethylene (TCE), cis-dichloroethene (cis-DCE) and trichloroethane (TCA). Aulenta et al. [15] developed an electrochemically assisted reductive dechlorinationin, which a polarized glassy carbon electrode (i.e. cathode), is used as an electron donor for the microbial reductive dechlorination of TCE to harmless ethane. Not only TCE could be removed using BES, carbon-based electrode polarized at $-0.55 \mathrm{~V} v s$. SHE can serve as direct electron donor for the microbial reductive dechlorination of chloroethenes (TCE and cis-DCE) to harmless non-chlorinated end-products [16].

Finally, it is important to highlight that conventional technologies for groundwater treatment have high operational costs, and that the BES-based technology potentially allows decreasing these costs considerably to meet groundwater standards, and the selective and sustainable removal of its pollutants. The effluent of BES is biologically stable, minimizing the potential health risks and other possible problems with the infrastructure of the water supply, such as clogging of point-of-use filters, biofouling of distribution pipes and bio corrosion [8]. Therefore, it exist a clear niche and demand on the groundwater treatment market.

\section{Acknowledgements}

This research was financially supported by the Spanish Government

*Corresponding author: Sebastià Puig, Laboratory of Chemical and Environmental Engineering (LEQUiA), Institute of the Environment, University of Girona, Girona, Spain, E-mail: sebastia@lequia.udg.cat

Received May 29, 2013; Accepted June 10, 2013; Published June 12, 2013

Citation: Coma M, Puig S (2013) Bioelectrochemical Treatment of Contaminated Groundwater. J Bioremed Biodeg 4: e135. doi:10.4172/2155-6199.1000e135

Copyright: $\odot 2013$ Coma M, et al. This is an open-a ccess article distributed under the terms of the Creative Commons Attribution License, which permits unrestricted use, distribution, and reproduction in any medium, provided the original author and source are credited. 
Citation: Coma M, Puig S (2013) Bioelectrochemical Treatment of Contaminated Groundwater. J Bioremed Biodeg 4: e135. doi:10.4172/21556199.1000 e135

(CTQ2011-23632, CONSOLIDERCSD2007-00055), and the Catalan Government (SGR2009-620). The authors acknowledge the assistance of Prof. Dr. M.D. Balaguer, Dr. J. Colprim and MSc. Narcis Pous.

\section{References}

1. Lovley DR (2006) Bug juice: harvesting electricity with microorganisms. Nat Rev Microbiol 4: 497-508.

2. Logan BE (2009) Exoelectrogenic bacteria that power microbial fuel cells. Nat Rev Microbiol 7: 375-381.

3. Logan BE, Rabaey K (2012) Conversion of wastes into bioelectricity and chemicals by using microbial electrochemical technologies. Science 337 : 686690.

4. Rabaey K, Rozendal RA (2010) Microbial electrosynthesis-Revisiting the electrical route for microbial production. Nat Rev Microbiol 8: 706-716.

5. Desloover J, Arends JB, Hennebel T, Rabaey K (2012) Operational and technical considerations for microbial electrosynthesis. Biochem Soc Trans 40: 1233-1238.

6. Puig S, Coma M, Desloover J, Boon N, Colprim J, et al. (2012) Autotrophic denitrification in microbial fuel cells treating low ionic strength waters. Environ Sci Technol 46: 2309-2315

7. Menció A, Boy M, Mas-Pla J (2011) Analysis of vulnerability factors that contro nitrate occurrence in natural springs (Osona Region, NE Spain). Sci Total Environ 409: 3049-3058.

8. Puig S, Serra M, Vilar-Sanz A, Cabré M, Bañeras L, et al. (2011) Autotrophic nitrite removal in the cathode of microbial fuel cells. Bioresour Technol 102 : $4462-4467$.
9. Desloover J, Puig S, Virdis B, Clauwaert P, Boeckx P, et al (2011) Biocathodic nitrous oxide removal in bioelectrochemical systems. Environ Sci Technol 45 10557-10566.

10. Vilar-Sanz A, Puig S, García-Lledó A, Trias R, Balaguer MD, et al. (2013) Denitrifying bacterial communities affect current production and nitrous oxide accumulation in a Microbial Fuel Cell. PLOS ONE 8: e63460.

11. Pous N, Puig S, Coma M, Balaguer MD, Colprim J, et al. (2013) Bioremediation of nitrate-polluted groundwater in a microbial fuel cell. J Chem Technol Biotechnol.

12. Liamleam W, Annachhatre AP (2007) Electron donors for biological sulfate reduction. Biotechnol Adv 25: 452-463.

13. Coma M, Puig S, Pous N, Balaguer MD, Colprim J (2013) Biocatalysed sulphate removal in a BES cathode. Bioresour Technol 130: 218-223.

14. Su W, Zhang L, Tao Y, Zhan G, Li D, et al. (2012) Sulfate reduction with electrons directly derived from electrodes in bioelectrochemical systems. Electrochem Commun 22: 37-40.

15. Aulenta F, Catervi A, Majone M, Panero S, Reale P, et al. (2007) Electron transfer from a solid-state electrode assisted by methyl viologen sustains efficient microbial reductive dechlorination of TCE. Environ Sci Technol 41 : 2554-2559.

16. Aulenta F, Reale P, Canosa A, Rossetti S, Panero S, et al. (2010) Characterization of an electro-active biocathode capable of dechlorinating trichloroethene and cis-dichloroethene to ethene. Biosens Bioelectron 25 : 1796-1802.
Citation: Coma M, Puig S (2013) Bioelectrochemical Treatment of Contaminated Groundwater. J Bioremed Biodeg 4: e135. doi:10.4172/21556199.1000 e135
Submit your next manuscript and get advantages of OMICS Group submissions

Unique features:

- User friendly/feasible website-translation of your paper to 50 world's leading language

Audio Version of published paper

Digital articles to share and explore

Special features:

250 Open Access Journal

20,000 editorial team

21 days rapid review process

Quality and quick editorial, review and publication processing

Indexing at PubMed (partial), Scopus, EBSCO, Index Copernicus and Google Scholar etc

Sharing Option: Social Networking Enabled

Authors, Reviewers and Editors rewarded with online Scientific Credits

Better discount for your subsequent articles

Submit your manuscript at: http://www.omicsonline.org/submission 